\title{
18
}

\section{Early Lapita subsistence: The evidence from Kamgot, Anir Islands, New Ireland Province, Papua New Guinea}

\author{
Glenn R. Summerhayes, Katherine Szabó, Andrew Fairbairn, \\ Mark Horrocks, Sheryl McPherson and Alison Crowther
}

\begin{abstract}
Over several decades there has been much discussion regarding the nature of Early Lapita subsistence, and in particular whether domesticated animals and horticulture were central components or whether initial Lapita subsistence strategies relied primarily upon marine resources. Here, we assess the evidence for subsistence during the earlier phases of occupation at Kamgot, Anir Islands, New Ireland Province, Papua New Guinea, particularly through the lens of terrestrial versus marine components.
\end{abstract}

\section{Introduction}

The most commonly accepted account for the initial presence of Lapita occupation in the Western Pacific is that it represented new people who brought with them new ideas, language and a translocated economy (Bellwood 1978; Green 1979; Kirch 1997, 2000; Spriggs 1997). This period is called Early Lapita (Summerhayes 2000a) and covers the first settlement phase dated from 3300-3000 cal. BP (Summerhayes 2010a:20; 2001a). Examples of economic introductions include pig, dog and chicken, all of which would have originated from Southeast Asia. The economy of these Early Lapita settlers was seen as broad-spectrum foraging, domestic animals, horticulture and arboriculture.

The basic gist of this model has been challenged by scholars for many reasons and from many angles. One of the less-accepted views does not recognise new people moving in with a translocated economy from the west (see Torrence 2016 for an updated version). It has been argued that there was no sudden intrusion of foreign migrants, but rather that new cultural traits were introduced over several centuries (Specht et al. 2014:89). This viewpoint is based on notions that there were no domesticated animals or cultigens associated with horticulture in the earliest Lapita settlements. That is, 'evidence for the orthodox view of the introduction of a foreign cultural package is weak' (Specht et al. 2014:92).

The notion that the Early Lapita settlers were horticulturalists who introduced pig, chicken and dog from Southeast Asia is also disputed (Specht et al. 2014). Although the nature of the subsistence economy of the Early Lapita site of Kamgot, Anir Islands, New Ireland Province, 
Papua New Guinea, has been discussed in a number of publications, noting the presence of pig and dog, and the presence of agriculture from the earliest Lapita levels (Summerhayes 2000b, 2007a, 2007b, 2010a, 2010b), there has been some publications stating the contrary (Grieg et al. 2016; Matisoo-Smith 2007; Specht et al. 2014). In a recent review, Specht et al. (2014:113, 115) stated that 'the presence of dogs during the formative Lapita phase in the Archipelago is questionable and the presence of pigs is ambiguous'. The evidence for the presence of pig and dog at Kamgot during Early Lapita will be specifically addressed here.

Kirch had argued that the earliest Lapita communities brought with them a 'transported landscape' (1997:217-220). Apart from pig, dog and chicken, he referred to horticulture and changes to the landscape. To date there have been problems in demonstrating the presence of horticulture within the Early Lapita settlements. Arguments for introduced crops in the Early Lapita sites were mainly based on linguistic or geomorphological evidence, leading to their dismissal by Specht et al. (2014:108).

It must be stressed that there are not many Early Lapita sites that are available for detailed analysis of midden material that can be used to model the subsistence economy of Early Lapita settlement. Two crucial factors must be considered. First, there are only a handful of Early Lapita sites that have actually been excavated. Of these, only a few have midden material for analysis, and these are from Mussau, Emirau, Anir and the Arawe Islands. Early Lapita sites from the north coast of New Britain and the Duke of York Islands have no faunal remains, due to the high acidity of the soils. Second, those Early Lapita sites where midden materials have been excavated were mostly deposited from stilt house occupation over water or on nearby sand spits. The deposition of faunal remains into water, for example, needs further attention as it would leave a different imprint or signature to deposition into intertidal sand spits, or on dry land. The aim of this chapter is to review and present the data of the fauna, mollusc and starch analyses on pottery from the Early Lapita archaeological site of Kamgot, to provide insights into the subsistence base at the site.

\section{Kamgot}

In Chapter 4 of this volume the depositional history of Kamgot is outlined in detail. The initial occupation at the site was directly over water, with upper intertidal habitation following in concert with the building up of a sand spit and Layer 2 sediments. The analysis of the following midden materials is concerned only with the Early Lapita levels. McPherson undertook the faunal analyses. The results for vertebrate bone are derived from analysis of Layers 2 and 3 of test pits (TP) 1, 2 and 23; Layer 3 only in TP17; and Layers 2 and 3 from TP21 and TP22. Analysis of molluscan remains was conducted by Szabó on materials from TPs 1, 2, 10, 14, 18, $19,20 \mathrm{~A}, 21 \mathrm{~A}, 21 \mathrm{~B}$ and 23.

\section{Vertebrate remains: Mammal}

A small proportion of the mammal assemblage is comprised of dog, pig, rat and cetacean bone. Twenty-one mammal bones could not be identified. To calculate the minimum number of individuals (MNI), it is necessary to deal with the problem of 'aggregation' (Grayson 1984). This refers to the issue of defining the appropriate provenance unit to use in the calculation. In this assemblage it is important to note the frequency of bone elements that occur more than once in the skeleton (e.g. teeth) and the frequency of element fragments (e.g. long bone shaft fragments). This can inevitably overestimate the quantity of mammals in this assemblage. The $335 \mathrm{mammal}$ bones represent only 11 individuals with a maximum of two individuals per species present. 
a)

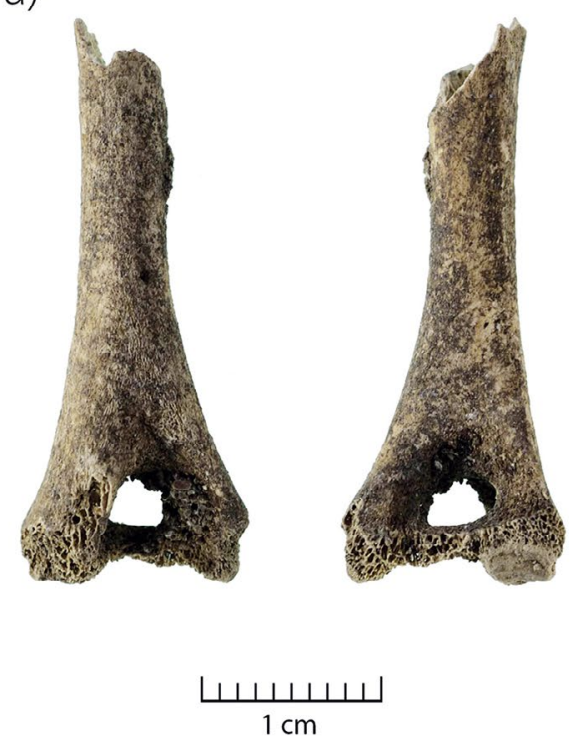

TR 21 sq. b, Spit 2, Layer 2 (SR65B)
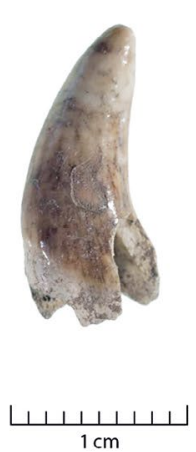

TP 23, Spit 4, Layer 2 (SR83P) b)
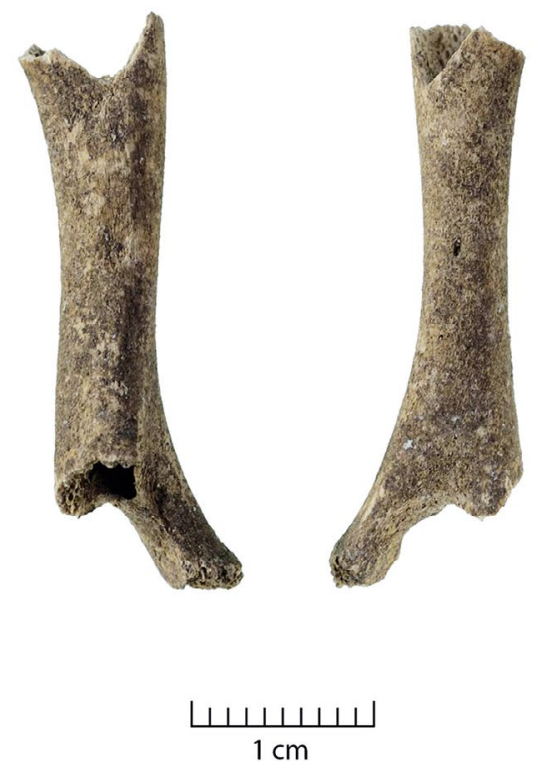

TR 21 sq. b, Spit 2, Layer 2 (SR65K)

d)

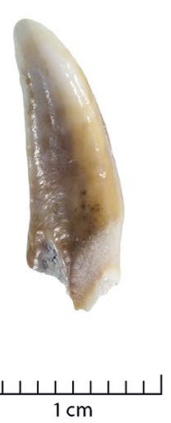

TP 22, Spit 9, Layer 3 (SR63E)

Figure 18.1. Two dog teeth and two possible dog bones.

Source: Glenn R. Summerhayes with assistance from Les $0^{\prime}$ Neil.

There are five definite dog remains with two possible identifications within the Early Lapita levels. The two possible are humeri that are very small and unfused in the assemblage, indicating a juvenile dog at the site (TP21). The five definite dog remains include: one metatarsal/metacarpal (TP2); two vertebrae, one a fragment (TP22) the other an atlas (TP2C); and two teeth, one from TP22, Layer 3, the other from TP23, Layer 2. Figure 18.1 shows the two teeth and two possible dog bones.

A dog bone (atlas) from the Early Lapita layers was sent for DNA analysis by Lisa Matisoo-Smith (vertebra from TP2C), but none could be extracted due to a lack of collagen. The two teeth were sent to Waikato for direct accelerator mass spectrometry (AMS) dating. Again, no date was possible as the protein in both was too degraded for measurement. This is a fundamental problem in dating 3000-year-old bone from these types of deposits due to a range of taphonomic processes. Another dog bone (metacarpal) was recovered from a later Lapita deposit (not Early Lapita) located at the eastern end of the site (TP10) within a shallow deposit and found in the interface of the topsoil and Layer 2 (depth $8 \mathrm{~cm}$ ). It was also sent for DNA analysis and subsequent dating at Waikato and returned a modern determination indicating that the deposits were mixed at this location and level. 
Six fragments of pig bone and one possible pig bone were identified. One bone, a vertebra, was found in TP2, Layer 2. Three came from TP21, Layer 2, two phalanges and one mandible, and two from TP22, Layer 2, one vertebra and the other a calcaneus.

Three marsupial bones were identified to species. One pademelon tooth (Thylogale brunii) from TP2B (Layer 2, spit 9); and two phalangerid bones from TP17 (Layer 3) (see Beavan Athfield et al. 2008). These were identified by Geoff Clark prior to the analyses undertaken in this article and were not included in Table 18.1 or MNI counts.

Six other bones were identified as marsupial, but a species could not be identified in the absence of reference material. These are separate from the 21 mammal bones that could not be identified. Reports referring to marsupial bones at other sites and zoological data of this region suggest that the marsupial bone is likely to be cuscus (Phalanger orientalis) or pademelon (T. brunii) (Flannery 1995; Kirch 2000; Marshall and Allen 1991; White et al. 1991). The marsupial bone identified in this assemblage has the most variation in elements across the site and was concentrated in those Early Lapita TPs 1, 2, 23 and 17 (from the western side of the site). Of the six marsupial bones which could not be attributed to species all were postcranial: two humeri, one vertebra, one tibia, one tarsal and one pelvis.

Three dolphin specimens are present in this assemblage based on vertebrae. All three are from TPs $2 a$ and $2 b$, with two found in Layer 3. Three rat bones were identified. A mandible from TP17, Layer 2, was sent to Matisoo-Smith for DNA analysis but not included in this analysis and therefore not included in Tables 18.1 and 18.2. Two other bones were a tibia and femur from TPs 21 and 22, respectively. Four human bones were identified, all from TP23 in Layer 2, spit 2. A tooth, mandible, metacarpal and skull fragment were found.

Table 18.1. Faunal MNI counts from Early Lapita, Kamgot.

\begin{tabular}{|c|c|c|c|c|c|c|c|c|c|c|}
\hline \multicolumn{11}{|c|}{ Taxon } \\
\hline \multicolumn{2}{|c|}{ Test pit } & 1 & $2 A$ & $2 B$ & $2 C$ & 17 & 21 & 22 & 23 & Subtotal \\
\hline \multicolumn{2}{|c|}{ Unidentified } & 2 & 3 & 4 & 3 & 1 & 1 & - & 3 & 17 \\
\hline \multirow[t]{3}{*}{ Bird } & Columbidae & - & - & - & - & - & - & 1 & - & 1 \\
\hline & Psittaciformes & - & - & 1 & - & - & - & - & - & 1 \\
\hline & Unidentified & 2 & 1 & 1 & - & - & 5 & 2 & 2 & 13 \\
\hline \multirow[t]{16}{*}{ Fish } & Acanthuridae & 1 & 3 & 4 & 1 & - & 7 & - & 10 & 26 \\
\hline & Balistidae & - & - & - & 1 & - & 1 & - & 1 & 3 \\
\hline & Carangidae & - & - & - & 1 & - & 2 & - & - & 3 \\
\hline & Diodontidae & 2 & - & 6 & 1 & - & 1 & - & 2 & 12 \\
\hline & Gempylidae & - & - & - & 1 & - & 1 & - & - & 2 \\
\hline & Labridae & 1 & 1 & - & - & - & 1 & - & - & 3 \\
\hline & Lethrinidae & 2 & & 1 & 1 & 2 & 1 & 1 & 3 & 11 \\
\hline & Lutjanidae & 2 & 1 & 1 & 3 & - & 4 & 1 & 5 & 17 \\
\hline & Monotaxis grandoculis & 1 & - & - & - & - & - & - & 1 & 2 \\
\hline & Muraenidae & 1 & - & - & - & 1 & - & - & - & 2 \\
\hline & \begin{tabular}{|l|} 
Pomadasyidae \\
\end{tabular} & - & - & - & - & 1 & - & - & - & 1 \\
\hline & Scaridae & 3 & 1 & 5 & 8 & 5 & 6 & 4 & 14 & 46 \\
\hline & Scombridae & 2 & 2 & 5 & 2 & - & 2 & - & 2 & 15 \\
\hline & Serranidae & - & 1 & 3 & 1 & - & - & - & 2 & 7 \\
\hline & Sphyraenidae & - & - & 2 & - & - & 1 & - & 2 & 5 \\
\hline & Unidentified & 15 & 17 & 24 & 46 & 17 & 43 & 17 & 91 & 270 \\
\hline
\end{tabular}




\begin{tabular}{|c|c|c|c|c|c|c|c|c|c|c|}
\hline \multicolumn{11}{|l|}{ Taxon } \\
\hline \multicolumn{2}{|l|}{ Test pit } & 1 & $2 \mathrm{~A}$ & $2 B$ & $2 C$ & 17 & 21 & 22 & 23 & Subtotal \\
\hline \multicolumn{2}{|c|}{ Unidentified } & 2 & 3 & 4 & 3 & 1 & 1 & - & 3 & 17 \\
\hline \multirow[t]{9}{*}{ Mammal } & ?Canis & - & - & - & - & - & 2 & - & - & 2 \\
\hline & ?Sus scrofa & - & - & - & - & - & - & - & 1 & 1 \\
\hline & Canis sp. & - & 1 & - & 1 & - & - & 2 & 1 & 5 \\
\hline & Cetacean sp. & - & 1 & 2 & - & - & - & - & - & 3 \\
\hline & Homo sapiens & - & - & - & - & - & - & - & 4 & 4 \\
\hline & Marsupial sp. & 1 & - & 1 & 2 & - & - & - & 2 & 6 \\
\hline & Rattus sp. & - & - & - & - & - & 1 & 1 & - & 2 \\
\hline & Sus scrofa & - & 1 & - & - & - & 3 & 2 & - & 6 \\
\hline & Unidentified & 2 & 2 & 4 & 1 & 1 & 2 & - & 3 & 15 \\
\hline \multirow[t]{4}{*}{ Reptile } & ?Lizard & - & - & - & - & - & - & - & 3 & 3 \\
\hline & Cheloniidae sp. & 4 & 5 & 11 & 7 & 5 & 8 & 4 & 13 & 57 \\
\hline & Unidentified & - & - & - & 1 & - & - & - & - & 1 \\
\hline & Total & 41 & 40 & 75 & 81 & 33 & 92 & 35 & 165 & 562 \\
\hline
\end{tabular}

Source: Authors' summary of data.

Table 18.2. Faunal NISP (number of identified specimens) counts from Early Lapita, Kamgot.

\begin{tabular}{|c|c|c|c|c|c|c|c|c|c|c|}
\hline \multicolumn{11}{|l|}{ Taxon } \\
\hline \multicolumn{2}{|l|}{ Test pit } & 1 & $2 \mathrm{~A}$ & $2 B$ & $2 C$ & 17 & 21 & 22 & 23 & Subtotal \\
\hline \multicolumn{2}{|c|}{ Unidentified } & 21 & 13 & 21 & 12 & 7 & 56 & 27 & 159 & 316 \\
\hline \multirow[t]{3}{*}{ Bird } & Columbidae & - & - & - & - & - & - & 1 & - & 1 \\
\hline & Psittaciformes & - & - & 1 & - & - & - & - & - & 1 \\
\hline & Unidentified & 2 & 1 & 1 & - & - & 5 & 2 & 2 & 13 \\
\hline \multirow[t]{16}{*}{ Fish } & Acanthuridae & 1 & 3 & 4 & 1 & - & 7 & - & 10 & 26 \\
\hline & Balistidae & - & - & - & 1 & - & 1 & - & 2 & 4 \\
\hline & Carangidae & - & - & - & 1 & - & 2 & - & - & 3 \\
\hline & Diodontidae & 3 & 5 & 17 & 5 & - & 7 & - & 10 & 47 \\
\hline & Gempylidae & - & - & - & 1 & - & 1 & - & - & 2 \\
\hline & Labridae & 1 & 1 & - & - & - & 1 & - & - & 3 \\
\hline & Lethrinidae & 3 & & 1 & 1 & 2 & 1 & 1 & 3 & 12 \\
\hline & Lutjanidae & 2 & 1 & 1 & 3 & - & 4 & 1 & 5 & 17 \\
\hline & Monotaxis grandoculis & 1 & - & - & - & - & - & - & 1 & 2 \\
\hline & Muraenidae & 1 & - & - & - & 1 & - & - & - & 2 \\
\hline & Pomadasyidae & - & - & - & - & 1 & - & - & - & 1 \\
\hline & Scaridae & 3 & 1 & 6 & 8 & 5 & 6 & 4 & 15 & 48 \\
\hline & Scombridae & 2 & 2 & 5 & 2 & - & 2 & - & 2 & 15 \\
\hline & Serranidae & - & 1 & 3 & 1 & - & - & - & 2 & 7 \\
\hline & Sphyraenidae & - & - & 2 & - & - & 1 & - & 2 & 5 \\
\hline & Unidentified & 34 & 37 & 74 & 128 & 43 & 107 & 22 & 124 & 569 \\
\hline \multirow[t]{9}{*}{ Mammal } & ?Canis & - & - & - & - & - & 2 & - & - & 2 \\
\hline & ?Sus scrofa & - & - & - & - & - & - & - & 1 & 1 \\
\hline & Canis sp. & - & 1 & - & 4 & - & - & 2 & 1 & 8 \\
\hline & Cetacean sp. & - & 1 & 2 & - & - & - & - & - & 3 \\
\hline & Homo sapien & - & - & - & - & - & - & - & 5 & 5 \\
\hline & Marsupial sp. & 1 & - & 1 & 2 & - & - & - & 2 & 6 \\
\hline & Rattus sp. & - & - & - & - & - & 1 & 1 & - & 2 \\
\hline & Sus scrofa & - & 1 & - & - & - & 6 & 2 & - & 9 \\
\hline & Unidentified & 2 & 3 & 6 & 1 & 1 & 3 & 5 & 3 & 24 \\
\hline
\end{tabular}




\begin{tabular}{|c|c|c|c|c|c|c|c|c|c|c|}
\hline \multicolumn{11}{|l|}{ Taxon } \\
\hline \multicolumn{2}{|l|}{ Test pit } & 1 & $2 \mathrm{~A}$ & $2 B$ & $2 C$ & 17 & 21 & 22 & 23 & Subtotal \\
\hline \multicolumn{2}{|c|}{ Unidentified } & 21 & 13 & 21 & 12 & 7 & 56 & 27 & 159 & 316 \\
\hline \multirow[t]{4}{*}{ Reptile } & ?Lizard & - & - & - & - & - & - & - & 3 & 3 \\
\hline & Cheloniidae sp. & 13 & 9 & 27 & 15 & 24 & 14 & 7 & 44 & 153 \\
\hline & Unidentified & - & - & - & 1 & - & - & - & - & 1 \\
\hline & Total & 90 & 80 & 172 & 187 & 84 & 227 & 75 & 396 & 1311 \\
\hline
\end{tabular}

Source: Authors' summary of data.

\section{Vertebrate remains: Reptile}

Less than 10 per cent of the vertebrate assemblage is reptile. The bulk of this material is comprised of turtle bone fragments and there is one fragment of bone from an unidentified reptile (mandible, TP2, Layer 2, spit 10). All the turtle bone is undiagnostic as to species and 76 per cent is carapace and plastron fragments. The rest is made up of small fragments, such as rib, scapula, phalange, radius, tibia, and long bone. Regardless of the high NISP value, the MNI for turtle in this assemblage is one. The highest concentrations of turtle bone were located in TPs 17 and 23.

\section{Vertebrate remains: Fish}

The fish bone $(\mathrm{n}=763)$ from the Kamgot excavations constitutes 58 per cent of the total assemblage analysed $(\mathrm{n}=1311)$. A total of 15 families and one species (Monotaxis grandoculis), was identified (Figure 18.2; Table 18.1). This does not include the category 'unidentified fish' $(n=569)$, which forms 75 per cent of the fish bone sample. The most common identified fish were inshore varieties such as taxa in the Scaridae, Diodontidae and Lethrinidae and Lutjanidae. Most of the fishing was inshore or from the reef, although tuna, dolphin, turtle and barracuda were also found.

Scaridae (parrotfish) and Diodontidae (porcupine pufferfish) are the most abundant fish (at 24.74 per cent and 24.23 per cent of bones, respectively (Table 18.3)). While parrotfish are found around the reefs, pufferfish are mostly found in shallow waters close to shore. The third most common family is Acanthuridae (surgeonfish), which inhabit the coral reefs and, like the parrotfish, live on algae. These fish are commonly caught by net or spear. Lutjanidae (snapper) and Lethrinidae (emperors) are next. Snappers are carnivores, feeding on crustaceans or other fish, while emperors are benthic feeders, eating small fish and invertebrates such as molluscs and crabs. Both are caught by line. The few pelagic taxa include the Scombridae (mackerels, tunas and bonitos). These make up only 8 per cent of fish bones. Table 18.2 examines the distribution of identified fish taxa derived from the NISP values across the excavated site. Fish bone is identified in almost every test pit with concentrations in $2 \mathrm{~B}, 2 \mathrm{C}, 20$ and $22(\mathrm{n}=565)$. These test pits also have the largest concentrations of unidentified fish bone. 

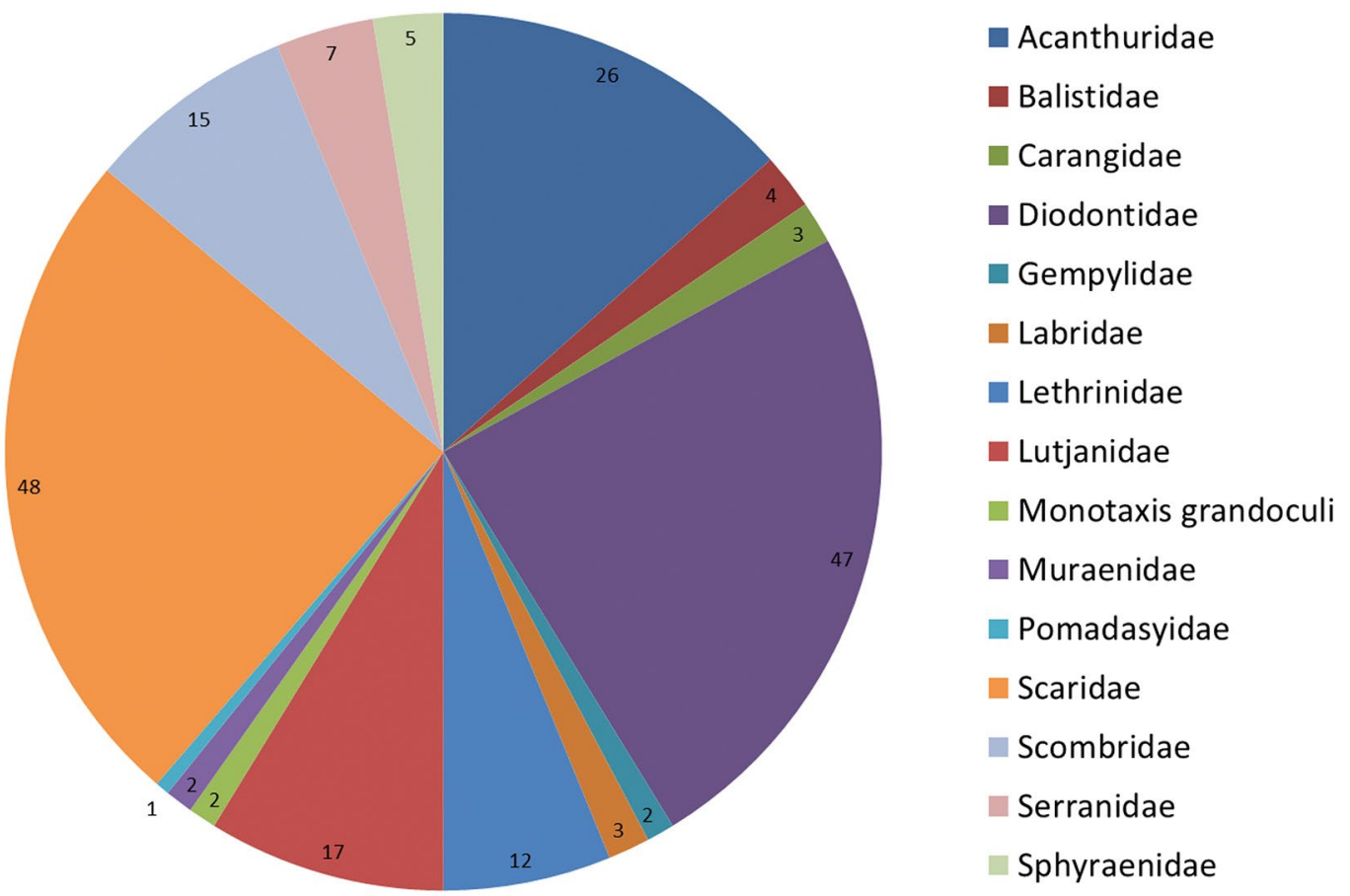

Figure 18.2. Pie diagram of fish families from Kamgot Early Lapita.

A total of 15 families and one species (Monotaxis grandoculis) was identified.

Source: Produced by the authors with assistance from Nick Hogg.

Table 18.3. Percentage of identified fish families, Early Lapita, Kamgot (NISP).

\begin{tabular}{|l|l|l|}
\hline Acanthuridae & 26 & $13.40 \%$ \\
\hline Balistidae & 4 & $2.06 \%$ \\
\hline Carangidae & 3 & $1.55 \%$ \\
\hline Diodontidae & 47 & $24.23 \%$ \\
\hline Gempylidae & 2 & $1.03 \%$ \\
\hline Labridae & 3 & $1.55 \%$ \\
\hline Lethrinidae & 12 & $6.19 \%$ \\
\hline Lutjanidae & 17 & $8.76 \%$ \\
\hline Monotaxis grandoculis & 2 & $1.03 \%$ \\
\hline Muraenidae & 2 & $1.03 \%$ \\
\hline Pomadasyidae & 1 & $0.52 \%$ \\
\hline Scaridae & 48 & $24.74 \%$ \\
\hline Scombridae & 15 & $7.73 \%$ \\
\hline Serranidae & 7 & $3.61 \%$ \\
\hline Sphyraenidae & 5 & $2.57 \%$ \\
\hline Total & 194 & $100.00 \%$ \\
\hline
\end{tabular}

Source: Authors' summary of data.
Most fish families are scattered across the test pits in varying quantities but with no particular concentrations. However, Scaridae is identified in most test pits, particularly in TP23, Acanthuridae are concentrated in TPs 21 and 23, and Diodontidae are concentrated in TP23 and TP2B. The largest quantity of each fish family is from TP23.

Based on the MNI calculations (Table 18.1), there is a minimum of 155 fish present in the Kamgot assemblage, with Scaridae being the most abundant, followed by Acanthuridae, Diodontidae and Lutjanidae. This is only a slightly different spread of fish families in comparison to using NISP quantities. It appears that on occasion, very large fish were being caught at this site. In TP21 a very large Scaridae dentary was identified. 


\section{Vertebrate remains: Bird}

There was very little bird bone identified in the assemblages and most was highly fragmented. The majority of the bird bones were long bone fragments without articular ends. As a result, the lack of crucial diagnostic features limited identifications (Steadman 2006:102). Only three bones had diagnostic features available for identification purposes. These identifications are only at a family and order level because of the absence of Pacific bird skeletal material in the reference collections.

Fifteen bird bones were identified in this assemblage (Tables 18.1 and 18.2). All but two bones were identified to element level only. The two bones that provided sufficient diagnostic features for identification include a Columbidae (corocoid) large pigeon from TP22, Layer 2, spit 2, and a Psittaciformes (parrot) tibiotarsus from TP2B, Layer 2, spit 6 .

Of note is the absence of bird bone from TP17, which was over water during the Early Lapita period. Bird bones do not settle well when deposited over water due to their lightweight structure (personal observation). Indeed, from TP17, 90 per cent of bone was fish or turtle. The rest consisted of a single mammal bone and seven unidentified bones.

\section{Molluscan remains}

A total of 187 marine and supra-littoral fringe species were identified within the Kamgot shell assemblage. Identified species and minimum number totals are presented in Table 18.4. This extensive species list reflects both the diversity of environments present within the Kamgot littoral catchment, as well as the species-rich nature of these niches themselves. Features of the local environment revealed by the structure and composition of the shell assemblage are further discussed here.

Species deriving from a number of major littoral environments are represented within the shell sample; however, the proportions deriving from each niche differ. A breakdown of the relative importance of various littoral niches, as calculated through MNI counts, is presented in Figure 18.3. Major littoral niches represented include the upper intertidal and splash zone, the reef-flat intertidal zone and the coarse coral sand niche. These three major zones are supplemented by a smaller contribution from silty/mudflat areas and freshwater environments. Table 18.5 presents the species-niche groupings used in the calculations of niche importance. Again, figures draw upon MNI quantifications.

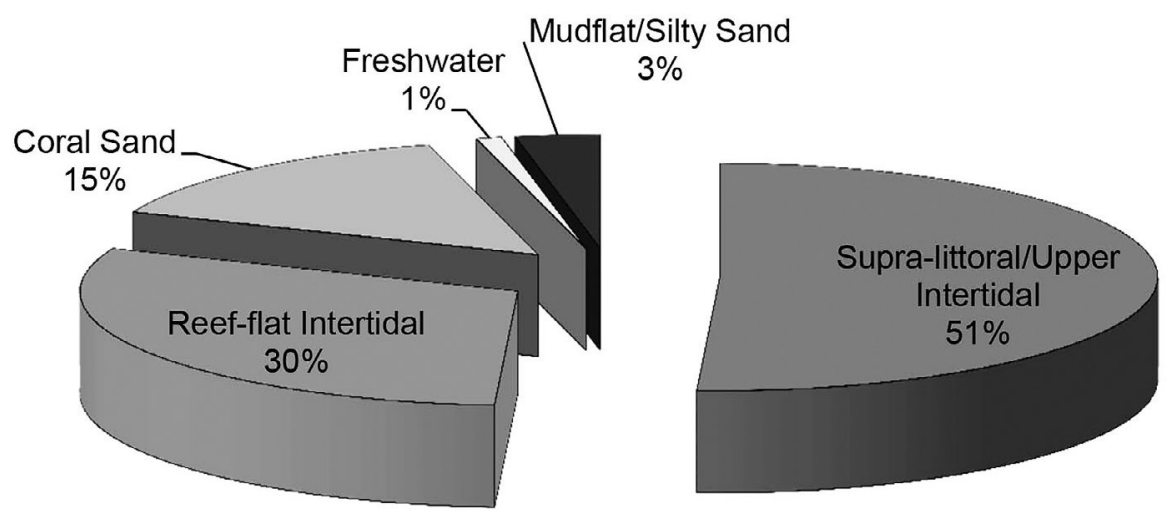

Figure 18.3. The supra-littoral and upper intertidal zone contribute the greatest number of shells within the overall sample.

Source: Produced by authors with assistance from Nick Hogg.

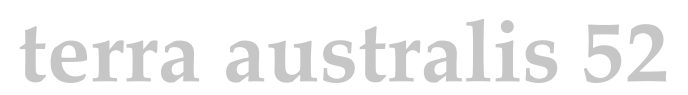


Table 18.4. Marine and supra-littoral fringe species identified within the Kamgot shell assemblage (minimum number totals [MNI]).

\begin{tabular}{|c|c|c|c|c|c|}
\hline Planaxis sulcatus & 2431 & Turbo argyrostomus & 21 & Periglypta риегрега (I) & 5 \\
\hline Neritina communis & 1263 & Turbo crassus & 21 & Acmaeidae sp. & 4 \\
\hline Pythia scarabaeus & 923 & Сургаеа spp. & 21 & Rhinoclavis asper & 4 \\
\hline Nerita undata & 520 & Fragum unedo & 21 & Natica onca & 4 \\
\hline Strombus mutabilis & 392 & Thais armigera & 19 & Cypraea tigris & 4 \\
\hline Turbo spp. operc & 367 & Drupa ricinus & 19 & Cypraea isabella & 4 \\
\hline Сургаеа moneta & 350 & Barbatia amygdalumtostum & 19 & (ypraea spp.(juv-bulla form) & 4 \\
\hline Cypraea annulus & 349 & Trochus niloticus & 18 & Cymatium labiosum & 4 \\
\hline Atactodea striata & 292 & Lambis lambis & 18 & Nassarius albescens & 4 \\
\hline Turbo setosus & 278 & Siphonaria sp. & 18 & Nassarius horridus & 4 \\
\hline Gafrarium pectinatum & 267 & Polinices melanostomus & 17 & Nassarius spp. & 4 \\
\hline Asaphis violascens & 237 & Patelloida saccharina & 15 & Stomatia phymotis & 3 \\
\hline Nerita plicata & 210 & Isognomon sp. (juv) & 15 & Turbo chrysostomus & 3 \\
\hline Tellina palatum & 154 & Bursa mammata & 14 & Nerita squamulata & 3 \\
\hline Cymatium nicobaricum & 127 & Tectus pyramis & 13 & Neripteron violacea & 3 \\
\hline Conus spp. & 122 & Barbatia velata & 12 & Vittina turrita & 3 \\
\hline Nerita polita & 87 & Rhinoclavis fasciata & 11 & Tectarius tectumpersicum (juv) & 3 \\
\hline Nassarius distortus & 82 & Vasum ceramicum & 11 & Cургаеа arabica & 3 \\
\hline T. niloticus (juvenile) & 80 & Batissa violacea & 11 & Drupa rubiscidaeus & 3 \\
\hline Chama iostoma & 76 & Ostraea sp. & 9 & Bursa granularis & 3 \\
\hline Nerita albicilla & 73 & Turbo marmoratus & 8 & Trachycardium enode & 3 \\
\hline Melanoides tuberculata & 72 & Cymatium pileare & 8 & Chama sp. & 3 \\
\hline Strombus gibberulus & 69 & Vasum turbinellus & 8 & Hippopus hippopus & 3 \\
\hline Trochus maculatus & 68 & Bulla vernicosa & 8 & Gafrarium tumidum & 3 \\
\hline Clypeomorus moniliferus & 62 & Cerithium columna & 7 & Periglypta reticulata & 3 \\
\hline Nerita chamaeleon & 54 & Clypeomorus brevis & 7 & Polyplacophora spp. & 2 \\
\hline Nerita costata & 51 & Cymatium muricinum & 7 & Tectus pyramis (juv) & 2 \\
\hline Turbo marmoratus operc. & 45 & Pyrene spp. & 7 & Nerita signata & 2 \\
\hline Thais tuberosa & 38 & Spondylus squamosus & 7 & Quoyia decollata & 2 \\
\hline Drupa morum & 38 & Tectus fenestratus & 6 & Strombidae spp. & 2 \\
\hline Rhinoclavis vertagus & 35 & Chrysostoma paradoxum & 6 & Polinices tumidus & 2 \\
\hline Hipponix conicus & 33 & Harpa amouretta & 6 & Сургаеа тарра & 2 \\
\hline Bursa spp. & 26 & Anadara antiquata & 6 & Thais spp. & 2 \\
\hline Modiolus philippinarum & 25 & Tridacna maxima & 6 & Morula sp. & 2 \\
\hline Strombus luhuanus & 23 & Angaria delphinus & 5 & Pleuropaca filamentosa & 2 \\
\hline Сургаеа caputserpentis & 23 & Hippopus hippopus (juv) & 5 & Marginella spp. & 2 \\
\hline
\end{tabular}


Table 18.4. Continued.

\begin{tabular}{|c|c|c|c|c|c|}
\hline Conus eburneus & 2 & Lambis truncata & 1 & Conus pulicarius & 1 \\
\hline Conus fulgetrum & 2 & Natica alapapilionis & 1 & Conus axelrodi & 1 \\
\hline Conus sponsalis & 2 & Natica sp. & 1 & Conus litteratus & 1 \\
\hline Atys cylindricus & 2 & Cypraea erosa & 1 & Conus leopardus & 1 \\
\hline Cassidula sp. & 2 & Cургаеа mauritania & 1 & c. litteratus/C. leopardus & 1 \\
\hline $\begin{array}{l}\text { Barbatia amygdalumtostum } \\
\text { (juv)(r) }\end{array}$ & 2 & Cypraea vitellus & 1 & Conus marmoreus & 1 \\
\hline Arca ventricosa & 2 & Cургаеа argus & 1 & Conus catus & 1 \\
\hline Isognomon ephippium (juv) & 2 & Cypraea eburnea & 1 & Conus virgo & 1 \\
\hline Lucinidae sp. & 2 & Thais intermedia & 1 & Terebra maculata & 1 \\
\hline Cardita variegata & 2 & Thais cf. hippocastanum & 1 & Terebra sp. & 1 \\
\hline Chama iostoma (juv) & 2 & Drupa sp. & 1 & Pyramidella sp. & 1 \\
\hline Glycydonta marica & 2 & Morula uva & 1 & Ellobium aurisjudae & 1 \\
\hline Patella sp. & 1 & Cronia biconica & 1 & Melampus cf. fasciatus & 1 \\
\hline Trochus histrio & 1 & Cantharus undosus & 1 & Arca avellana & 1 \\
\hline Pseudostomatella decolorata & 1 & Bursa rubeta & 1 & Glycymeris sp. (juv) & 1 \\
\hline Stomatolina rubra & 1 & Bursa cruentata & 1 & Codakia punctata & 1 \\
\hline Turbo marmoratus (juv) & 1 & Cymatium nicobaricum (juv) & 1 & Spondylus cf. squamosus (juv) & 1 \\
\hline Turbo petholatus & 1 & Cymatium spp. & 1 & Trachycardium sp. & 1 \\
\hline Turbo bruneus & 1 & Cymatium spp.(juv) & 1 & Chama lazarus & 1 \\
\hline Turbo spp. & 1 & Gyrineum sp. & 1 & Tridacna maxima (juv) & 1 \\
\hline Nerita plicata (juv) & 1 & Pleuropaca trapezium & 1 & Tridacna squamosa & 1 \\
\hline Clypeolum auriculatum & 1 & Peristernia cf. nassatula & 1 & Tridacna squamosa (juv) & 1 \\
\hline Neritopsis radula & 1 & Peristernia sp. (juv) & 1 & Tridacna gigas & 1 \\
\hline Terebralia palustris & 1 & Latirus sp. & 1 & Donax cuneatus & 1 \\
\hline Terebralia sp. & 1 & Latirolagena smaragdula & 1 & Tellina scobinata & 1 \\
\hline Cerithium nodulosum & 1 & Nassarius gruneri & 1 & Tellina staurella & 1 \\
\hline Rhinoclavis sinensis & 1 & Nassarius dorsatus & 1 & Tellina staurella (juv) & 1 \\
\hline Rhinoclavis kochi & 1 & Phalium sp. (?) & 1 & Tellina sp. & 1 \\
\hline Clypeomorus traillii & 1 & Malea pomum & 1 & Asaphis violascens (juv) & 1 \\
\hline Clavocerithium taeniatum & 1 & Oliva sp. & 1 & Gafrarium pectinatum (juv) & 1 \\
\hline Tectarius sp. (juv) & 1 & Pterygia cf. dactylus & 1 & Tapes litteratus & 1 \\
\hline Littorina undulata & 1 & Vexillum sp. & 1 & Nautilus sp. & 1 \\
\hline Littorina coccinea & 1 & Vasum spp. & 1 & & \\
\hline Littorina pintado & 1 & Vasum spp. (juv) & 1 & & \\
\hline Littorina sp. & 1 & Tonna perdix & 1 & & \\
\hline Lambis lambis (juv) & 1 & Conus ebraeus & 1 & & \\
\hline
\end{tabular}

Source: Authors' summary of data. 
As can be seen in Figure 18.5, the supra-littoral and upper intertidal zone contribute the greatest number of shells within the overall sample. The upper intertidal and supra-littoral or 'splash' zones are typically characterised by a range of small gastropod species, well adapted to spending considerable amounts of time out of water. To avoid desiccation, taxa such as Nerita plicata, Littorina spp. and Melampus spp. often hide in clusters in rock crevices and are active at nights or during rainy days (Demond 1957:287).

The hard reef-flat intertidal zone is an area characterised by high diversity of species relative to total biomass - that is, there are many species, but relatively few of each as compared to other zones such as soft-shore intertidal niches (Hook 1999:28, 30). The reef-flat intertidal component of the Kamgot assemblage reflects this diversity with at least 99 species being represented within a total of 2905 MNI, with many of these species being represented by only one or a few individuals. While the hard reef-flat contributes 30 per cent of the molluscan assemblage, bivalves and gastropods deriving from coral sand niches compose 15 per cent. A total of 55 species contribute to this coral sand total. This again reflects the diverse nature of this habitat within the greater coral reef ecosystem. Given the greater proportion of colonial bivalves in coral sand substrates, it can be expected that there will be greater unevenness in representation, with a larger concentration of common bivalve species (e.g. Asaphis violascens and Atactodea striata) and with a more varied selection of gastropods represented by lower numbers of individuals. The exceptions within the gastropods, as can be seen in Table 18.5, are certain members of the Strombidae-in particular, Strombus mutabilis and Strombus luhuanus, which tend to aggregate in large groups in sandy and weedy habitats (de Bruyne 2003).

Mudflat habitats are characterised by finer sediment particular size, which is related to the input of terrestrial sediments. As with the coral sand niche, colonial bivalves are prevalent, and this results in a mollusc sample that is more uneven than is typical of the hard reef-flat. Within the Kamgot sample, this niche is dominated by the bivalve Gafrarium pectinatum, which has a rather wide environmental tolerance, being able to inhabit silty mud through to weedy coral sand. That $G$. pectinatum is accompanied by low-level occurrences of various members of the Nassariidae, Bulla vernicosa and Terebralia palustris, however, indicates that muddy environments are being exploited. The level of input of this niche is low in relation to the high molluscan biomass of muddy/mangrove areas generally. This indicates that muddy habitats were not present in the immediate vicinity of the site.

In addition to the muddy-silty niche, there is also a relatively minor contribution from freshwater habitats. This is dominated by the small gastropod Melanoides tuberculata and supplemented by freshwater neritids (Gastropoda: Neritidae), and 11 individuals of the freshwater bivalve Batissa violacea. As with the muddy-silty niche, this would tend to indicate that mollusc-bearing freshwater environments were located within the greater site catchment, although are perhaps not immediately local and/or were not being exploited to any great degree.

'Natural' shell, other than in situ death assemblages, has been mentioned in Chapter 4 as being characterised by carnivorous gastropod borings, attrition through beach-rolling and indications of hermit crab utilisation. A further key indicator of naturally introduced shell is the presence of bioerosion-largely through the action of microscopic (clionid) boring sponges. These sponges act underwater on calcareous materials and tunnel out connected chambers that leave distinctive honeycomb structures upon and within the shell (see Szabó 2005 for further detail). 
Of importance at Kamgot is the lack of evidence for clionid boring on shells in all material analysed by Szabó. Clionid sponges do not act on material that is not submerged at all times, so this reinforces the interpretation that the shell midden material, which dominantly derived from Layer 2, was deposited directly onto land or into the intertidal zone.

Within the assumed culturally generated sample, minus the supra-littoral fraction, the majority of molluscan remains derive from either the hard reef-flat intertidal zone, or the soft coral sand zone. As mentioned above in terms of the nearshore palaeoenvironment, the hard-shore reefflat niche is represented by 2905 individuals within 99 different species. While this diversity is partially a reflection of the high diversity of the reef-flat zone, it also signals a fine-grained gathering strategy that allows us to see this inherent diversity reflected within the sample.

Molluscs associated with the intertidal coarse coral sand niche represent 15 per cent of the overall Kamgot shell assemblage. This sample is dominated by gregarious gastropods, such as Strombus luhuanus and Strombus mutabile, and colonial bivalves such as Atactodea striata, Quidnipagus (=Tellina) palatum and Asaphis violascens. These species are supplemented by a variety of less common and/or solitary species including surface carnivores and scavengers such as members of the Nassariidae (Nassarius distortus, N. albescens) and Naticidae (Mammilla (=Polinices) melanostoma, Naticarius (=Natica) onca and N. alapapilionis) families, among others. As with the hard reef-flat sample, the diversity of the habitat is reflected in the composition of the assemblage, implying a fine-grained gathering strategy. The bivalves, as well as some of the gastropods such as the naticids and cerithids, burrow into the sand and can only be visually detected through raised trails marking their passage or holes that allow exposure to the siphon. Gathering, therefore, requires either looking for these traces or fortuitous collection through the action of digging through the sand. In either case, the exact species and the size of the individual is unknown until collection, making selective gathering a trickier endeavour than with visible individuals.

Only a few species $(\mathrm{n}=10)$ deriving from environments characterised by siltier sand are represented in the Kamgot sample. Together these comprise 3 per cent of the overall shell sample. The sample is dominantly composed of the bivalve species Gafrarium pectinatum (MNI=268). This colonial species is supplemented by much smaller numbers of other bivalves (Anadara antiquata and Gafrarium tumidum) as well as surface-dwelling scavengers such as the various members of the Nassariidae and herbivores such as Bulla vernicosa. The low diversity of mollusc species represented from this niche, along with the predominance of Gafrarium pectinatum, suggests that a coarse- rather than fine-grained gathering strategy was employed while searching for molluscs in muddy environments. 
Table 18.5. Species-niche groupings used in the calculations of niche importance.

\begin{tabular}{l}
\hline \multicolumn{2}{|l|}{ Pelagic } \\
\hline Nautilus sp. \\
\begin{tabular}{|l|c|}
\hline \multicolumn{2}{|l|}{ Supra-littoral/upper intertidal } \\
\hline Planaxis sulcatus & 2431 \\
\hline Theodoxus oualaniensis + Neritina communis & 1362 \\
\hline Pythia scarabaeus & 824 \\
\hline Nerita plicata & 211 \\
\hline Siphonaria sp. & 18 \\
\hline Patelloida saccharina & 15 \\
\hline Tectarius tectumpersicum (juv) & 3 \\
\hline Tectarius sp.juv) & 1 \\
\hline Littorina undulata & 1 \\
\hline Littorina coccinea & 1 \\
\hline Littorina pintado & 1 \\
\hline Littorina sp. & 1 \\
\hline Ellobium aurisjudae & 1 \\
\hline Melampus cf. fasciatus & 1 \\
\hline Cassidula sp. & 2 \\
\hline Total & 4873 \\
\hline
\end{tabular}
\end{tabular}

\begin{tabular}{|c|c|}
\hline \multicolumn{2}{|l|}{ Reef-flat intertidal } \\
\hline Isognomon sp. (juv) & 15 \\
\hline Tectus pyramis & 15 \\
\hline Bursa mammata & 14 \\
\hline Barbatia velata & 12 \\
\hline Vasum ceramicum & 11 \\
\hline Ostraea sp. & 9 \\
\hline Turbo marmoratus & 9 \\
\hline Vasum turbinellus & 8 \\
\hline Cymatium pileare & 8 \\
\hline Spondylus squamosus & 8 \\
\hline Cerithium columna & 7 \\
\hline Pyrene spp. & 7 \\
\hline Tridacna maxima & 7 \\
\hline Clypeomorus brevis & 7 \\
\hline Tectus fenestratus & 6 \\
\hline Chrysostoma paradoxum & 6 \\
\hline Angaria delphinus & 5 \\
\hline Hippopus hippopus (juv) & 5 \\
\hline Acmaeidae sp. & 4 \\
\hline Сургаеа tigris & 4 \\
\hline Cypraea isabella & 4 \\
\hline Cymatium labiosum & 4 \\
\hline Stomatia phymotis & 3 \\
\hline Turbo chrysostomus & 3 \\
\hline Nerita squamulata & 3 \\
\hline Сургаеа агаbica & 3 \\
\hline Drupa rubiscidaeus & 3 \\
\hline Bursa granularis & 3 \\
\hline Chama sp. & 3 \\
\hline Hippopus hippopus & 3 \\
\hline Polyplacophora spp. & 2 \\
\hline Nerita signata & 2 \\
\hline Сургаеа тарра & 2 \\
\hline Thais spp. & 2 \\
\hline Morula sp. & 2 \\
\hline Pleuropaca filamentosa & 2 \\
\hline Arca ventricosa & 2 \\
\hline Isognomon ephippium (juv) & 2 \\
\hline Quoyia decollata & 2 \\
\hline Conus fulgetrum & 2 \\
\hline Tridacna squamosa & 2 \\
\hline Vasum spp. & 2 \\
\hline Cymatium spp. & 2 \\
\hline Patella sp. & 1 \\
\hline Trochus histrio & 1 \\
\hline Pseudostomatella decolorata & 1 \\
\hline Stomatolina rubra & 1 \\
\hline
\end{tabular}

\begin{tabular}{|l|c|}
\hline Reef-flat intertidal & \\
\hline Nerita undata & 520 \\
\hline Cypraea moneta & 350 \\
\hline Cypraea annulus & 349 \\
\hline Turbo setosus & 278 \\
\hline Cymatium nicobaricum & 128 \\
\hline Conus spp. & 122 \\
\hline Trochus niloticus & 98 \\
\hline Nerita polita & 87 \\
\hline Chama iostoma & 78 \\
\hline Nerita albicilla & 73 \\
\hline Trochus maculatus & 68 \\
\hline Clypeomorus moniliferus & 62 \\
\hline Nerita chamaeleon & 54 \\
\hline Nerita costata & 51 \\
\hline Thais tuberosa & 38 \\
\hline Drupa morum & 38 \\
\hline Hipponix conicus & 33 \\
\hline Bursa spp. & 26 \\
\hline Modiolus philippinarum & 25 \\
\hline Cypraea spp. & 25 \\
\hline Cypraea caputserpentis & 23 \\
\hline Turbo argyrostomus & 21 \\
\hline Turbo crassus & 21 \\
\hline Barbatia amygdalumtostum & 21 \\
\hline Thais armigera & 19 \\
\hline Drupa ricinus & 19 \\
\hline Lambis lambis & 19 \\
\hline & \\
\hline
\end{tabular}




\begin{tabular}{|c|c|}
\hline \multicolumn{2}{|l|}{ Reef-flat intertidal } \\
\hline Turbo petholatus & 1 \\
\hline Turbo bruneus & 1 \\
\hline Turbo spp. & 1 \\
\hline Neritopsis radula & 1 \\
\hline Thais intermedia & 1 \\
\hline Thais cf. hippocastanum & 1 \\
\hline Drupa sp. & 1 \\
\hline Morula uva & 1 \\
\hline Cronia biconica & 1 \\
\hline Bursa rubeta & 1 \\
\hline Bursa cruentata & 1 \\
\hline Pleuropaca trapezium & 1 \\
\hline Peristernia cf. nassatula & 1 \\
\hline Peristernia sp. (juv) & 1 \\
\hline Chama lazarus & 1 \\
\hline Tridacna gigas & 1 \\
\hline Arca avellana & 1 \\
\hline Cypraea mauritania & 1 \\
\hline Cypraea erosa & 1 \\
\hline Cypraea argus & 1 \\
\hline Сургаеа vitellus & 1 \\
\hline Cургаеа eburnea & 1 \\
\hline Gyrineum sp. & 1 \\
\hline Latirus sp. & 1 \\
\hline Latirolagena smaragdula & 1 \\
\hline Conus ebraeus & 1 \\
\hline Conus marmoreus & 1 \\
\hline Conus catus & 1 \\
\hline Cantharus undosus & 1 \\
\hline Clypeomorus traillii & 1 \\
\hline Total & 2905 \\
\hline
\end{tabular}

\begin{tabular}{|l|c|}
\hline Coral Sand & \\
\hline Nassarius albescens & 4 \\
\hline Trachycardium enode & 3 \\
\hline Periglypta reticulata & 3 \\
\hline Strombidae spp. & 2 \\
\hline Polinices tumidus & 2 \\
\hline Lucinidae sp. & 2 \\
\hline Cardita variegata & 2 \\
\hline Glycydonta marica & 2 \\
\hline Tellina staurella & 2 \\
\hline Conus eburneus & 2 \\
\hline Atys cylindricus & 2 \\
\hline Marginella spp. & 2 \\
\hline Conus sponsalis & 2 \\
\hline Cerithium nodulosum & 1 \\
\hline Rhinoclavis sinensis & 1 \\
\hline Rhinoclavis kochi & 1 \\
\hline Lambis truncata & 1 \\
\hline Natica alapapilionis & 1 \\
\hline Natica sp. & 1 \\
\hline Phalium sp. & 1 \\
\hline Malea pomum & 1 \\
\hline Oliva sp. & 1 \\
\hline Tonna perdix & 1 \\
\hline Glycymeris sp. (juv) & 1 \\
\hline Codakia punctata & 1 \\
\hline Trachycardium sp. & 1 \\
\hline Donax cuneatus & 1 \\
\hline Tellina scobinata & 1 \\
\hline Tellina sp. & 1 \\
\hline Tapes litteratus & 1 \\
\hline Terebra maculata & 1 \\
\hline Terebra sp. & 1 \\
\hline Conus litteratus & 1 \\
\hline Conus leopardus & 1 \\
\hline C. litteratus/C. leopardus & 1 \\
\hline Conus virgo & 1 \\
\hline Vexillum sp. & 1 \\
\hline Conus pulicarius & 1 \\
\hline Conus axelrodi & 1 \\
\hline Pterygia cf. dactylus & 1 \\
\hline Pyramidella sp. & 1 \\
\hline
\end{tabular}

\begin{tabular}{|l|c|}
\hline Coral Sand & 392 \\
\hline Strombus mutabilis & 292 \\
\hline Atactodea striata & 238 \\
\hline Asaphis violascens & 154 \\
\hline Tellina palatum & 82 \\
\hline Nassarius distortus & 69 \\
\hline Strombus gibberulus & 35 \\
\hline Rhinoclavis vertagus & 23 \\
\hline Strombus luhuanus & 21 \\
\hline Fragum unedo & 17 \\
\hline Polinices melanostomus & 11 \\
\hline Rhinoclavis fasciata & 7 \\
\hline Cymatium muricinum & 6 \\
\hline Harpa amouretta & 5 \\
\hline Periglypta puerpera & 4 \\
\hline Rhinoclavis asper & 4 \\
\hline Natica onca & \\
\hline
\end{tabular}




\begin{tabular}{|l|c|}
\hline Freshwater & 72 \\
\hline Melanoides tuberculata & 11 \\
\hline Batissa violacea & 3 \\
\hline Neripteron violacea & 3 \\
\hline Vittina turrita & 1 \\
\hline Clypeolum auriculatum & 90 \\
\hline Total & \\
\hline
\end{tabular}

\begin{tabular}{|l|c|}
\hline Mudflat/ silty sand \\
\hline Gafrarium pectinatum & 267 \\
\hline Bulla vernicosa & 8 \\
\hline Anadara antiquata & 6 \\
\hline
\end{tabular}

\begin{tabular}{|l|c|}
\hline Mudflat/ silty sand \\
\hline Nassarius horridus & 4 \\
\hline Nassarius spp. & 4 \\
\hline Gafrarium tumidum & 3 \\
\hline Terebralia palustris & 1 \\
\hline Terebralia sp. & 1 \\
\hline Gafrarium pectinatum (juv) & 1 \\
\hline Nassarius gruneri & 1 \\
\hline Nassarius dorsatus & 1 \\
\hline Total & 297 \\
\hline
\end{tabular}

Source: Authors' summary of data.

\section{Botanical remains: Starch}

This section reviews the analyses on the identification of starch in soil samples undertaken by Mark Horrocks and on pottery by Alison Crowther (2005, 2009a).

\section{Soil samples}

Horrocks undertook analysis of starch and other plant material from a soil sample from Early Lapita deposits in TP1 (north wall) and TP23 (Layer 2, spit 2). The analysis undertaken in this study includes starch grains and several other types of plant material, which were extracted using the standard density separation method (Horrocks 2005; Pearsall 2015). These other types present comprise amyloplasts, xylem cells, phenolic inclusions, calcium oxalate crystals, sheets of epidermal cells and occasional pollen grains and fern spores.

Several types of starch were identified in the samples. Small amounts of starch grains consistent with the tubers of greater yam (Dioscorea alata) were found in the samples from TP1. Xylem cells consistent with the tubers of the yam family (Dioscoreaceae) were also found in TP1.

Styloids, a type of calcium oxalate crystal, consistent with the leaf of Freycinetia and/or Pandanus were found in all samples. These two genera are members of the Pandanaceae. Several pollen and spore types were also identified in the samples. These comprise coconut (Cocos nucifera), Elaeocarpaceae and Moraceae pollen, and Pteris, monolete psilate and trilete regulate fern spores in the sample from TP1, and a monolete psilate fern spore in the sample from TP23.

\section{Pottery}

Twenty plain sherds from TP17, Layer 3, were sent to Crowther for analysis as part of research for her BA honours dissertation (2005) and later her PhD (2009). Her BA research used direct microscopic observation of the pottery surfaces to locate starch granules and calcium oxalate raphides in situ. This preliminary study identified starch and calcium oxalate raphides characteristic of Colocasia esculenta (taro) on all 20 sherds, as well as raphides in the associated sediments (Crowther 2005). Crowther's PhD research extended the study to more detailed analysis of starch granules in transmitted light to determine whether the C. esculenta identification could be confirmed using other features along with evidence of morphological changes associated with cooking. Further chemical testing of the crystals identified as raphides was also necessary to differentiate them from calcite crystals, which may occur naturally within the calcareous Kamgot sediments (Crowther 2009b). Details of the preparation and analysis of samples can be found in Crowther (2009a). The archaeological starch granules were identified using a modern starch 
reference collection representing the main edible aroids, yams, fruit and arboreal starches that form the basis of Pacific subsistence systems, as well as published descriptions (e.g. Fullagar et al. 2006; Loy 1994; see Crowther 2009a for further details).

Fifteen of the 20 sherds produced starch grains ( $\mathrm{n}=278$ granules plus one large cluster of $>100$ granules). Starches typical of modern $C$. esculenta corms were confirmed on two sherds: ERA2.7 and ERA2.8. ERA2.8 produced the largest taro-type starch assemblage, comprising the large cluster noted above (Figure 18.4a-c) as well as 130 isolated granules (Figure 18.4d-e; see Figure 18.5 for modern comparative example). Only two taro-type granules were present in the residue extract from ERA2.7. The taro-type starches were identified based on their small size, which in the Kamgot assemblage did not exceed $8 \mu \mathrm{m}$ (mean $5.45 \mu \mathrm{m}$ ), their round to spherical to sub-round to sub-spherical shape (in two and three dimensions respectively), and the presence of multiple flat facets on their surfaces. The facets have slightly rounded edges when viewed with regular objectives (e.g. Figure $18.4 \mathrm{f}-\mathrm{g}$ ), but appear sharper when examined using oil immersion, as in the examples shown in Figure 18.4c-e. These features as well as extinction crosses and birefringence characteristic of starch granules were observed on all taro-type granules including individuals within the aggregate, and all granules also stained with IKI, confirming their identification as starch. Fullagar et al. (2006:598) propose that the faceted surface morphology of $C$. esculenta starch granules is particularly distinctive and enables their differentiation from transitory starch granules of similar size, which are found in the photosynthetic tissues of many plants. The large aggregate found on ERA2.8 is also most likely to derive from a storage organ rather than leaf, stem or similar plant tissue, where dense starch deposits are not known to accumulate (Fullagar et al. 2006; Gott et al. 2006; Haslam 2004). The remaining 148 starch granules identified in the Kamgot assemblage have not yet been identified, either because they do not match any food plants in the modern reference set or overlap morphologically with multiple reference taxa (see Crowther 2009a for further descriptions).
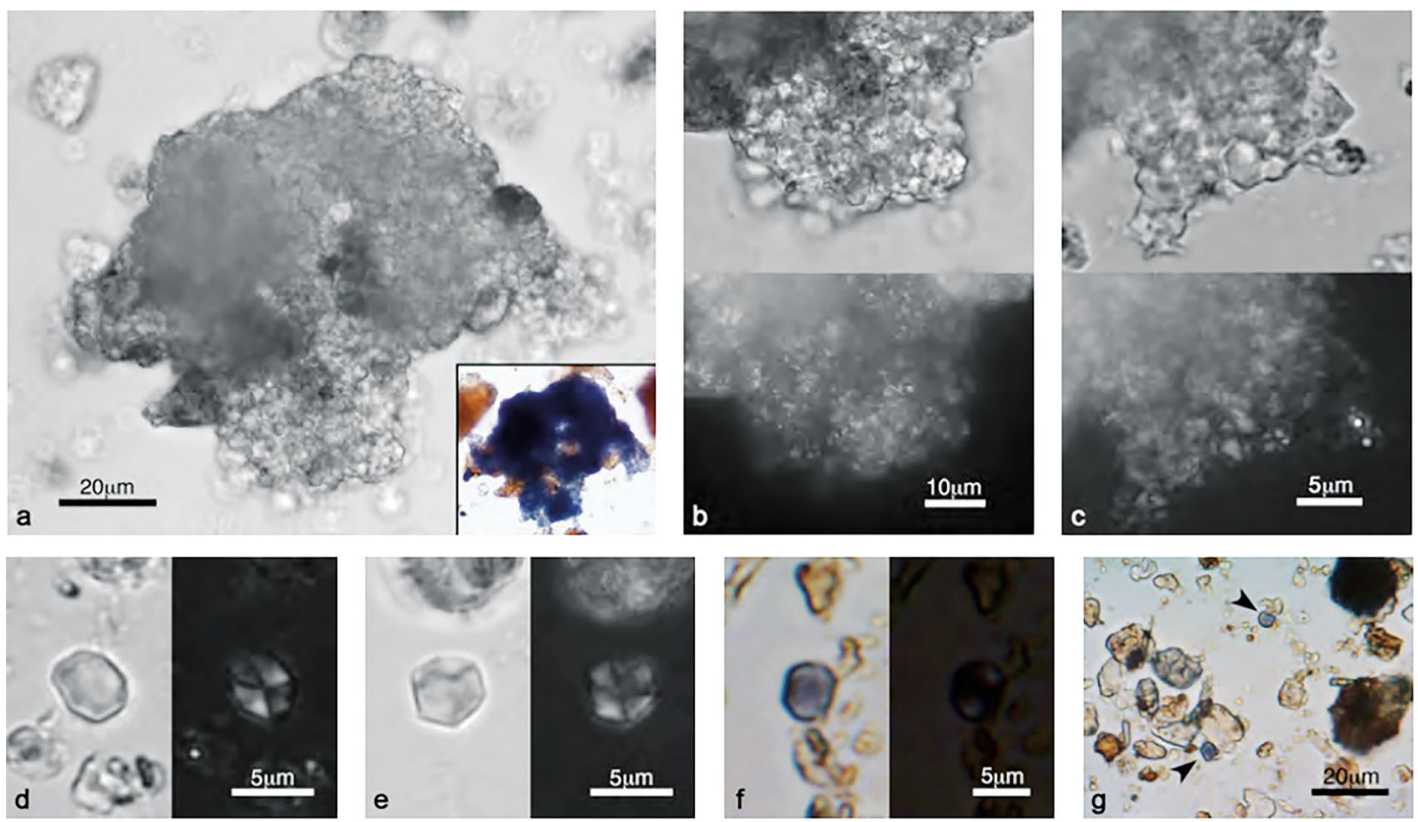

Figure 18.4. Examples of $C$. esculenta-type starches recovered from the Kamgot Lapita sherds.

(A) large cluster of granules from ERA2.8 (inset: IKI-stained); $(B-C)$ detail of large cluster in $(A)$; $(D-G)$ isolated granules from ERA2.8; ((A-E) oil immersion; ( $\mathrm{F}-\mathrm{G})$ IKI-stained; (B-C) lower and (D-G) right are under cross-polars).

Source: Alison Crowther. 

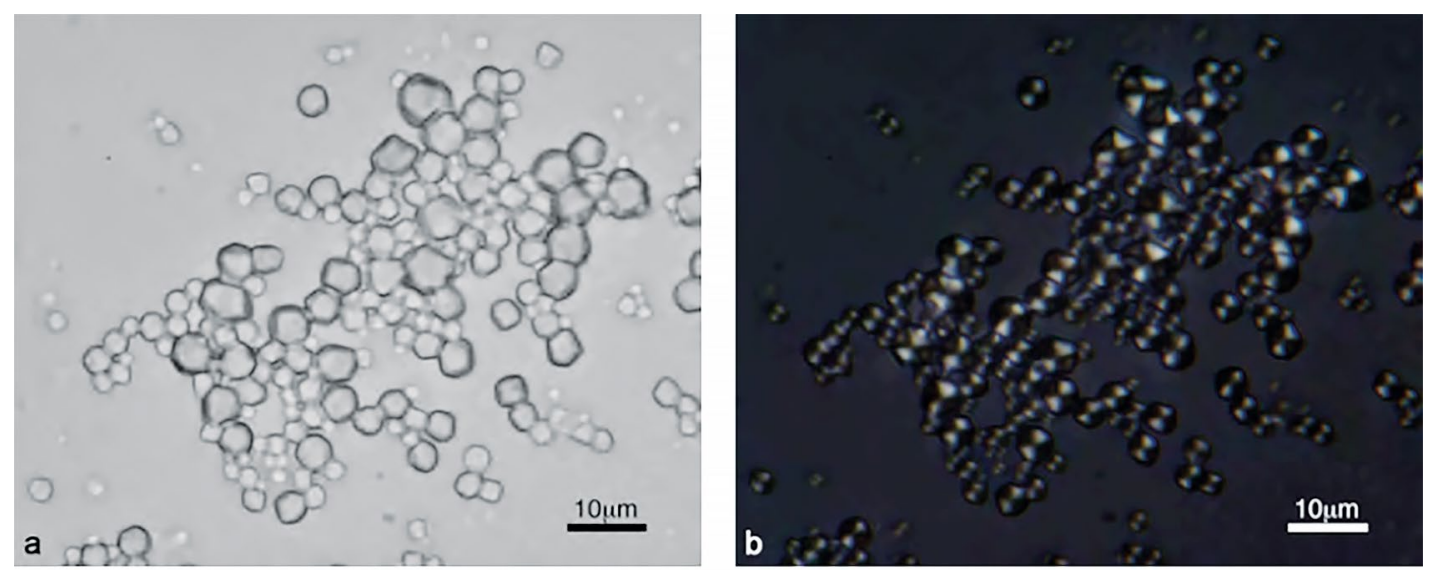

Figure 18.5. Modern reference $C$. esculenta starch granules.

(B) under cross-polars. (Note: photos taken without oil immersion.)

Source: Alison Crowther.

The preservation state of the Kamgot pottery starches reveal few clues as to possible past food-processing activities. The majority of the assemblage, including all of those identified as $C$. esculenta, were in a good state of preservation with no evidence of damage from food processing or post-depositional degradation ( $\mathrm{n}=242,87$ per cent). A small number of granules (all belonging to unidentified morphotypes) showed evidence of mechanical damage such as tearing or cracking $(n=34,14$ per cent), which could result either from grinding or pounding during food processing, or from post-depositional abrasion. Only two granules ( 0.7 per cent) in the entire starch assemblage were gelatinised, indicating that they had been cooked $(n=2,0.7$ per cent). Neither of the gelatinised granules were recovered from the four sherds with charred food crusts. Even though taro and many other Pacific staple crops need to be cooked to be made edible, the near-absence of gelatinised starches within the residue assemblages is unsurprising given the extreme morphological changes that starch granules undergo during cooking (irreversible swelling and disruption, in most cases leading to complete granule disintegration). These alterations are particularly pronounced in taro starch, owing to its small size. These changes occur more rapidly and extensively in moisture-rich cooking systems, as would be expected in the Pacific where steaming and boiling are typically preferred, and where root crop staples have naturally high water contents (Crowther 2012). Gelatinised starch granules are also much more susceptible to enzymatic decay and are therefore less likely to survive in archaeological food residues than undamaged granules (Denham and Barton 2006; Haslam 2004). No starch granules with visible pits, channels or exposed lamellae were observed in the assemblage, such as would result from enzymatic attack during fermentation, a method of food preservation used widely across the Pacific today (Pollock 1992).

Chemical tests indicate that the crystals identified previously as calcium oxalate raphides were likely misidentified and are actually morphologically similar calcite crystals from the site sediments (see Crowther 2009b). While the presence of raphides in association with taro-type starches would otherwise significantly strengthen the C. esculenta identification, their absence is not surprising; others have noted the generally low frequency of raphides occurring in both experimental and archaeological residues of taro on stone tools (Fullagar et al. 2006).

The pottery residue evidence demonstrates more conclusively the presence and probable processing of the important staple food plant Colocasia esculenta at this Early Lapita site, adding to the already accumulated archaeological starch record for the use and likely translocation of this crop across the Pacific by prehistoric seafaring migrants (e.g. Horrocks and Bedford 2005; 
Horrocks and Nunn 2007). The location of the sherds used in this analysis is also important. The sherds supplied to Crowther consisted of 20 undecorated pottery sherds from Layer 3 of TP 17. The sherds from this layer would have been deposited into water from a stilt house. It is logical to argue that consumption of the taro from the pots occurred in this stilt house. Whether the cooking was undertaken in the stilt house or on a nearby sand spit and then transferred to the stilt house is unknown. Charcoal is absent from deposits from TP17, which would be expected with occupation directly over water. The presence of starchy cooking residues on undecorated sherds is consistent with the hypothesis that plain Lapita pottery was used for utilitarian tasks (Kirch 1997:150-151; Summerhayes 2000c:302-303, 2001b:61).

Whether taro was collected from wild sources or cultivated at Kamgot cannot be ascertained directly from the pottery residues, as similar starch morphotypes may occur in both (Denham and Barton 2006:246). Although Anir is located within the endemic range of wild taro, where it grows naturally in swamps and along streams (Matthews 1995; Spriggs 1996:527), Lebot (1999:623) argues that it is unlikely colonising groups would have collected and distributed wild taro genotypes because they are extremely small and acrid and thus less practical as food.

\section{Macrobotanical remains}

Macrobotanical analysis was undertaken by Andrew Fairbairn. Plant remains were recovered from TP2C through flotation of 230 litres of soil from Layers 2 and 3 (plus the transitional zone) using simple bucket methods. Plant remains were recovered from the non-floating sample fraction in the field, with the floating (light) fraction analysed in the University of Queensland Archaeology Lab. Specimens were identified using light and scanning electron microscopy in comparison to specimens in the analyst's reference collection (see Table 18.6).

Table 18.6. Plant macrofossils recorded in Layers 2-3 at Kamgot test pit $2 \mathrm{C}$.

\begin{tabular}{|c|c|c|c|c|c|}
\hline & & Spit & 2 to 10 & 11 & 12 \\
\hline & & Layer & 2 & 2 to 3 & 3 \\
\hline & & Depth & $10-110 \mathrm{~cm}$ & $110-120 \mathrm{~cm}$ & $120-130 \mathrm{~cm}$ \\
\hline & & Soil volume (litres) & 180 & 40 & 10 \\
\hline & & Economic sum & 135 & 17 & 7 \\
\hline & & Density (items per litre) & 0.75 & 0.43 & 0.70 \\
\hline Taxon & English name & Component & Count & Count & Count \\
\hline Pandanus sp. Polydrupe & Screwpine/pandanus & Endocarp, charred & 1 & - & - \\
\hline cf. Colocasia & Таго & Parenchyma & 6 & 2 & - \\
\hline Cocos nucifera & Coconut & Endocarp, charred & 81 & 14 & 6 \\
\hline cf. cocos nucifera & Coconut & Endocarp, charred & 17 & - & 1 \\
\hline cf. Musa & Banana & Epidermis & 2 & - & - \\
\hline cf. Inocarpus fagiferus & Pacific chestnut & Pod, charred & 1 & - & - \\
\hline Canarium sp. & Pacific almond & Endocarp, charred & 16 & - & - \\
\hline cf. Canarium sp. & Pacific almond & Endocarp, charred & 10 & 1 & - \\
\hline cf. Terminalia catappa & Sea almond & Endocarp, charred & 2 & - & - \\
\hline Indeterminate & - & Wood & 70 & 21 & - \\
\hline Indeterminate & - & Non-woody stem & 10 & - & 19 \\
\hline Indeterminate & - & Vesicular matter & 13 & - & 4 \\
\hline Indeterminate & - & Nutshell & 83 & 14 & 3 \\
\hline Indeterminate & - & Parenchyma & 9 & 1 & - \\
\hline Indeterminate & - & Seed & 1 & - & - \\
\hline Indeterminate & - & Fibre bundles & 9 & 4 & - \\
\hline
\end{tabular}

Source: Authors' summary of data. 
Only charred plant macrofossil remains were recovered from the samples, with endocarp/nutshell dominating the assemblages and various other plant structures present, many of which could not be identified taxonomically. Of the recovered remains, 158 could be identified with an economic plant to some level of taxonomic specificity. Fragments of wood charcoal, non-woody stems and bundles of fibres, plus a range of unidentifiable endocarp/nutshell, were also present. The specimens were highly fragmented, with few larger than $4 \mathrm{~mm}$ in diameter and most specimens c. $2 \mathrm{~mm}$ maximum dimension. This greatly restricted the potential for identification.

Dominating the economic assemblage ( $73-100$ per cent of the three stratigraphic layers) were the endocarp/nutshell fragments of coconut (Cocos nucifera), clearly identifiable due to the presence of secretory cavities in a dense ground tissue and large reconstructed fruit radius. Second in abundance was Pacific almond/galip (Canarium sp.), forming 20 per cent of fragments in Layer 2, including fragments with preservation of the locule inner surface. Species were not identifiable, but the anatomy matches the economic species $C$. salomonense, $C$. indicum and $C$. harveyi. A single well-preserved fragment of Pandanus endocarp was also recovered, having a distinctive locule inner surface cell pattern, ground tissue and large vascular bundles. The specimen probably derived from a polydrupe species. Nutshell and pods from Canarium sp. and Inocarpus fagiferus were also identified, though they were poorly preserved. Two fragments of banana leaf epidermis were present in Layer 2, identified on the basis of their cell structure, presence of crypted stomata and longitudinal wrinkling. Among the indeterminate remains, wood and nutshell were very common, with non-woody stem and fibre bundles, similar to those found in palm fruits, present, signifying burning of a wide range of plant structures. Several discrete but unidentified nutshell types were present in the assemblage.

Vegetative parenchyma was also present in small quantities in the assemblage, especially in Layer 2. Several fragments of probable Colocasia (taro) were identified on the basis of the dense, spherical cell structure and presence of secretory cavities, as well as randomly distributed vascular bundles, typical of monocotyledonous plants. Other parenchyma specimens with a differing structure were also present.

\section{Land, sea and Kamgot}

The collective evidence from faunal and floral remains at Kamgot presents a picture of diversity, and a balance between land and sea and the produced versus the gathered and hunted. The evidence from the fish, shellfish and marine reptile and mammal remains at Kamgot clearly demonstrates that different niches were being utilised for food procurement, and that these niches ranged from those in close proximity to the site to those more distant. The molluscan remains indicate that soft and hard substrates were being visited on gathering forays, as well as mudflats not in the immediate vicinity of the site. The fishbone data suggest inshore predation of benthic and reef edge zones. Scarids, acanthurids and lethrinids are all fish taxa common to these zones, in addition to balistids, labrids, lutjanids and serranids (Walter 1998:69-70). Fishing methods in these zones include fishing from watercraft just off the reef edge or catching from on the reef edge (Walter 1998:69-70). The presence of Scombridae and Sphyraenidae are suggestive of offshore fishing using trolling lures and angling methods. Most of the specimens are from relatively small individuals. The cetacean vertebrae and tooth indicates the utilisation of some larger marine mammals. As expected with exploitation of some of these species, a number of fishhooks were recovered from Anir (Szabó and Summerhayes 2002). A similar exploitation of fish is seen from the Early Lapita sites of Mussau and Tamuarawai (Emirau) and also the later Lapita site of Watom (Butler 1988; Green and Anson 2000:52; Kirch et al. 1991; Summerhayes et al. 2010; see also Ono et al. this volume). Fishhooks are generally also found at these sites. 
The collective evidence for terrestrial fauna, whether wild, translocated or domesticated, is more restricted but nevertheless present. Pig and dog are present in the earliest Lapita levels at Kamgot. This is in line with, for example, the faunal evidence from Mussau (Kirch et al. 1991:154), where despite the presence of pig in early deposits, the dramatic surge in pig bones in Post-Lapita deposits suggests that intensive pig husbandry was not a feature of the Early Lapita economy. It is interesting to look at what constitutes an important presence of a dog or pig. Pig and dog are found in the earliest Lapita levels, but their low number does not necessarily equate to rarity in Lapita life. Kirch put it well when he wrote: 'Unfortunately, negative evidence often proves to be a weak or erroneous basis for hypothesis development' (Kirch 1997:194). As he later noted (2000:110), dog and pig were present in Lapita contexts but never in large numbers. What does this inform us about consumption patterns? Pigs today are rarely eaten in day to day sustenance but consumed at important social occasions. It would be unusual to find large quantities of pig bones in any midden unless they accumulated over a long period of time from permanent settlements. Dogs are also rarely eaten in many societies. Their absence in a kitchen midden should not to be equated with their absence from society. Thus, the absence or scarcity of either pig or dog indicates that they were not eaten in large numbers and probably not as an everyday occurrence, unlike fish and shellfish.

Along with the dog bone and plant evidence, it is nevertheless clear that animals were being kept and gardens established and maintained. The Kamgot botanical assemblage is comparable to the well-preserved, waterlogged assemblages from Lapita settlements in the Arawes (Matthews and Gosden 1997) and Mussau Islands (Kirch 1989; Lepofsky 1992), which contained a wide variety of economic species, especially fruit and nut trees. The Kamgot assemblage is taxonomically less diverse, but that is unsurprising as fewer taxa are likely to be both preserved and identifiable in charred assemblages. The presence of tuber remains, including taro, among the macrobotanical remains confirms the results of residue analysis at the site. Interestingly the waterlogged assemblages from the Arawes and Mussau Islands did not contain similar remains, again probably reflecting the selective nature of different forms of preservation, tubers not being well preserved in waterlogged environments.

The nature of Early Lapita occupation is also critical in understanding the nature of subsistence. It was argued, on the basis of pottery production, to have been characterised by highly mobile societies, with sedentary occupation occurring later in Middle Lapita sites (Summerhayes 2000a). These mobile societies still allowed people to practise horticulture and bring with them domesticates from the west. It must be made clear that the deposit at Kamgot did not accumulate over a long period of time, and the sand deposit with midden material could have been deposited over a few months. People also returned to this occupation area, which we know from TP20. But the Early Lapita phase did not equate to permanent settlement. There is also evidence for later occupation at other locales on the Anir Island group (see Summerhayes 2000b), and nearby Tanga (see Cath-Garling 2017). The situation is akin to the suggestion of Gosden and Pavlides (1994:169) that settlements were 'spots on the landscape to which people returned on a regular basis'. This is what Early Lapita is in a nutshell. These early colonists cleared gardens they created for taro, yam and banana, and the nut-bearing trees that provided a ready supply of food. They introduced animals such as dog and pig, and they utilised the outer reef resources as evidenced from the earliest Lapita levels.

Kamgot as an Early Lapita settlement provides unique insights into subsistence from a number of different data sets. Yet such a subsistence base was introduced as a transported landscape (Kirch 1997:217), not into permanent settlements (as seen in communities today in Melanesia) but into a highly mobile and interactive society that subsequently expanded into Remote Oceania. Permanent Lapita settlement was only found later in the Middle Lapita period (Summerhayes 2000a).

\section{terra australlis 52}




\section{Acknowledgements}

We would like to thank the National Museum and Art Gallery of Papua New Guinea, the National Research Institute of Papua New Guinea, the New Ireland Provincial Government, and, most important of all, the people of Anir for allowing this work to be undertaken. We thank Nick Hogg for help with the Excel cross tabulations to produce the faunal graphs. This research was funded from a large Australian Research Council grant (A59530950) awarded to Summerhayes. Lastly, we would like to thank Stuart Bedford and Matthew Spriggs for their patience.

\section{References}

Beavan Athfield, N., R.C. Green, J. Craig, B. McFadgen and S. Bickler 2008. Influence of marine sources on $14 \mathrm{C}$ ages: Isotopic data from Watom Island, Papua New Guinea inhumations and pig teeth in light of new dietary standards. Journal of the Royal Society of New Zealand 38:1-23. doi.org/10.1080/ 03014220809510543.

Bellwood, P. 1978. Man's conquest of the Pacific. Collins, Auckland, Sydney and London.

Butler, V.L. 1988. Lapita fishing strategies: The faunal evidence. In P.V. Kirch and T.L. Hunt (eds), Archaeology of the Lapita Cultural Complex: A critical review, pp. 99-115. Thomas Burke Memorial Washington State Museum Research Report 5. Burke Museum, Seattle.

Cath-Garling, S. 2017. Evolutions or revolutions? Interaction and transformation at the 'Transition' in Island Melanesia. University of Otago Studies in Archaeology 27. University of Otago, Dunedin.

Crowther, A. 2005. Starch residues on undecorated Lapita pottery from Anir, New Ireland. Archaeology in Oceania 40:62-66. doi.org/10.1002/j.1834-4453.2005.tb00586.x.

Crowther, A. 2009a. Investigating Lapita subsistence and pottery use through microscopic residues on ceramics: Methodological issues, feasibility and potential. Unpublished $\mathrm{PhD}$ thesis, University of Queensland, Brisbane.

Crowther, A. 2009b. Reviewing raphides: Issues with the identification and interpretation of calcium oxalate crystals in microfossil assemblages. In A. Fairbairn, S. O'Connor and B. Marwick (eds), New directions in archaeological science, pp. 105-118. ANU E Press, Canberra. doi.org/10.22459/ TA28.02.2009.08.

Crowther, A. 2012. The differential survival of native starch during cooking and implications for archaeological analyses: A review. Anthropological and Archaeological Sciences 4:221-235. doi.org/ 10.1007/s12520-012-0097-0.

de Bruyne, R.H. 2003. The complete encyclopedia of shells. Rebo Publishers, Lisse.

Demond, J. 1957. Micronesian reef-associated gastropods. Pacific Science 11(3):275-341.

Denham, T.P. and H. Barton 2006. The emergence of agriculture in New Guinea: A model of continuity from pre-existing foraging practices. In D. Kennett and B. Winterhalder (eds), Behavioral ecology and the transition to agriculture, pp. 237-264. University of California Press, Berkeley.

Flannery, T. 1995. Mammals of New Guinea. Robert, Browns and Associates, Queensland.

Fullagar, R.L.K., J. Field, T.P. Denham and C.J. Lentfer 2006. Early and mid-Holocene tool-use and processing of taro (Colocasia esculenta), yam (Dioscorea sp.) and other plants at Kuk Swamp in the highlands of Papua New Guinea. Journal of Archaeological Science 33:595-614. doi.org/10.1016/ j.jas.2005.07.020. 
Gosden, C. and C. Pavlides 1994. Are islands insular? Landscape vs. seascape in the case of the Arawe Islands, Papua New Guinea. Archaeology and Oceania 29:162-171. doi.org/10.1002/ arco.1994.29.3.162.

Gott, B., H. Barton, D. Samuel and R. Torrence 2006. Biology of starch. In R. Torrence and H. Barton (eds), Ancient starch research, pp. 35-45. Left Coast Press, Walnut Creek, California.

Grayson, D.K. 1984. Quantitative zooarchaeology: Topics in the analysis of archaeological fauna. Academic Press, San Diego.

Green, R.C. 1979. Lapita. In J.D. Jennings (ed.), The prehistory of Polynesia, pp. 27-60. Harvard University Press, Cambridge Mass. doi.org/10.4159/harvard.9780674181267.c3.

Green, R.C. and D. Anson 2000. Excavations at Kainapirina (SAC), Watom Island, Papua New Guinea. New Zealand Journal of Archaeology 20(1998):29-94.

Greig, K., R. Walter and E. Matisoo-Smith 2016. Dogs and people in Southeast Asia and the Pacific. In M. Oxenham and H.R. Buckley (eds), The Routledge handbook of bioarchaeology in Southeast Asia and the Pacific Islands, pp. 462-482. Routledge, London. doi.org/10.4324/9781315725444.

Haslam, M. 2004. The decomposition of starch grains in soils: Implications for archaeological residue analysis. Journal of Archaeological Science 31:1715-1734. doi.org/10.1016/j.jas.2004.05.006.

Hook, P. 1999. The world of seashells. PRC Publishing, London.

Horrocks, M. 2005. A combined procedure for recovering phytoliths and starch residues from soils, sedimentary deposits and similar materials. Journal of Archaeological Science 32:1169-1175. doi.org/ $10.1016 /$ j.jas.2005.02.014.

Horrocks, M. and S. Bedford 2005. Microfossil analysis of Lapita deposits in Vanuatu reveals introduced Araceae (aroids). Archaeology in Oceania 40:67-74. doi.org/10.1002/j.1834-4453.2005.tb00587.x.

Horrocks, M. and P.D. Nunn 2007. Evidence for introduced taro (Colocasia esculenta) and lesser yam (Dioscorea esculenta) in Lapita-era (c. 3050-2500 cal. BP) deposits from Bourewa, southwest Viti Levu Island, Fiji. Journal of Archaeological Science 34:739-748. doi.org/10.1016/j.jas.2006.07.011.

Kirch, P.V. 1989. Second millennium BC arboriculture in Melanesia: Archaeological evidence from the Mussau Islands. Economic Botany 43:225-240. doi.org/10.1007/BF02859865.

Kirch, P.V. 1997. The Lapita peoples: Ancestors of the Oceanic world. Blackwell, Oxford.

Kirch, P.V. 2000. On the road of the winds: An archaeological history of the Pacific Islands before European contact. University of California Press, Berkeley.

Kirch, P.V., T.L. Hunt, M.I. Weisler, V.L. Butler and M.S. Allen 1991. Mussau Islands prehistory: Results of the 1985-86 excavations. In J. Allen and C. Gosden (eds), Report of the Lapita Homeland Project, pp. 144-163. Occasional Papers in Prehistory 20. Department of Prehistory, RSPacS, The Australian National University, Canberra.

Lebot, V. 1999. Biomolecular evidence for plant domestication in Sahul. Genetic Resources and Crop Evolution 46(6):619-628. doi.org/10.1023/A:1008748504038.

Lepofsky, D. 1992. Arboriculture in the Mussau Islands, Bismarck Archipelago. Economic Botany 46:192-211. doi.org/10.1007/BF02930638.

Loy, T.H. 1994. Methods in the analysis of starch residues on prehistoric stone tools. In J.G. Hather (ed.), Tropical archaeobotany: Applications and new developments, pp. 86-114. Routledge, London. 
Marshall, B. and J. Allen 1991. Excavations at Panakiwuk Cave, New Ireland. In J. Allen and C. Gosden (eds), Report of the Lapita Homeland Project, pp. 59-91. Occasional Papers in Prehistory 20. Department of Prehistory, RSPacS, The Australian National University, Canberra.

Matisoo-Smith, E. 2007. Animal translocations, genetic variation, and the human settlement of the Pacific. In J. Friedlaender (ed.), Genes, language, and culture history in the Southwest Pacific, pp. 157-170. Oxford University Press, New York. doi.org/10.1093/acprof:oso/9780195300307.003.0010.

Matthews, P.J. 1995. Aroids and the Austronesians. Tropics 4:105-126. doi.org/10.3759/tropics.4.105.

Matthews, P.J. and C. Gosden 1997. Plant remains from waterlogged sites in the Arawe Islands, West New Britain Province, Papua New Guinea: Implications for the history of plant use and domestication. Economic Botany 51(2):121-133. doi.org/10.1007/BF02893102.

Pearsall, D.M. 2015. Paleoethnobotany: A handbook of procedures. Left Coast Press, Walnut Creek.

Pollock, N. 1992. These roots remain: Food habits in islands of the central and eastern Pacific since western contact. Institute for Polynesian Studies, Hawai'i.

Specht, J., T. Denham, J. Goff and J.E. Terrell 2014. Deconstructing the Lapita Cultural Complex in the Bismarck Archipelago. Journal of Archaeological Research 22(2):89-140. doi.org/10.1007/s10814013-9070-4.

Spriggs, M. 1996. Agriculture and what went before in island Melanesia. In D.R. Harris (ed.), The origins and spread of agriculture and pastoralism in Eurasia, pp. 524-537. UCL Press, London.

Spriggs, M. 1997. The Island Melanesians. Blackwell, Oxford.

Steadman, D.W. 2006. Extinction and biogeography of tropical Pacific birds. University of Chicago Press, Chicago.

Summerhayes, G.R. 2000a. Lapita interaction. Terra Australis 15. Department of Archaeology and Natural History and the Centre for Archaeological Research, The Australian National University, Canberra.

Summerhayes, G.R. 2000b. Recent archaeological investigations in the Bismarck Archipelago, Anir, New Ireland Province, Papua New Guinea. Bulletin of the Indo-Pacific Prehistory Association 19:167-174.

Summerhayes, G.R. 2000c. What's in a pot? In A.J. Anderson and T. Murray (eds), Australian archaeologist: Collected papers in honour of Jim Allen, pp. 291-307. Coombs Academic Publishing, The Australian National University, Canberra.

Summerhayes, G.R. 2001a. Defining the chronology of Lapita in the Bismarck Archipelago. In G.R. Clark, A.J. Anderson and T. Vunidilo (eds), The archaeology of Lapita dispersal in Oceania. Papers from the Fourth Lapita Conference, June 2000, Canberra, Australia, pp. 25-38. Terra Australis 17. Pandanus Books, The Australian National University, Canberra.

Summerhayes, G.R. 2001b. Lapita in the far west: Recent developments. Archaeology in Oceania 36(2):53-63. doi.org/10.1002/j.1834-4453.2001.tb00478.x.

Summerhayes, G.R. 2007a. The rise and transformation of Lapita in the Bismarck Archipelago. In S. Chui and C. Sand (eds), From Southeast Asia to the Pacific: Archaeological perspectives on the Austronesian expansion and the Lapita Cultural Complex, pp. 129-172. Centre for Archaeological Studies, Research Centre of Humanities and Social Sciences. Academia Sinica, Taipei.

Summerhayes, G.R. 2007b. Island Melanesian pasts—A view from archaeology. In J. Friedlaender (ed.), Genes, language and culture history in the Southwest Pacific, pp. 10-35. Oxford University Press, New York. doi.org/10.1093/acprof:oso/9780195300307.003.0002.

Summerhayes, G.R. 2010a. Lapita interaction-An update. In M. Gadu and H-m. Lin (eds), 2009 International Symposium on Austronesian Studies, pp. 11-40. National Museum of Prehistory, Taitong. 
Summerhayes, G.R. 2010b. The emergence of Lapita in the Bismarck Archipelago. In C. Sand and S. Bedford (eds), Lapita: Ancêtres Océaniens/Oceanic ancestors, pp. 92-101. Museé du quai Branly and Somogy, Paris.

Summerhayes, G.R., L. Matisoo-Smith, H. Mandui, J. Allen, J. Specht, N. Hogg and S. McPherson 2010. Tamuarawai (EQS): An Early Lapita site on Emirau, New Ireland, PNG. Journal of Pacific Archaeology 1:62-75.

Szabó, K. 2005. Technique and practice: Shell-working in the Western Pacific and Island Southeast Asia. Unpublished PhD thesis, The Australian National University, Canberra.

Szabó, K. and G. Summerhayes 2002. Worked shell artefacts—New data from Early Lapita. In S. Bedford, C. Sand and D. Burley (eds), Fifty years in the field: Essays in honour and celebration of Richard Shutler Jr's archaeological career, pp. 91-100. New Zealand Archaeological Association Monograph 25. New Zealand Archaeological Association, Auckland.

Torrence, R. 2016. Social resilience and long-term adaptation to volcanic disasters: The archaeology of continuity and innovation in the Willaumez Peninsula, Papua New Guinea. Quaternary International 394:6-16. doi.org/10.1016/j.quaint.2014.04.029.

Walter, R. 1998. Anai'o: The archaeology of a fourteenth century Polynesian community in the Cook Islands. New Zealand Archaeological Association Monograph 22. New Zealand Archaeological Association, Auckland.

White, J.P., T.F. Flannery, R. O’Brien, R.V. Hancock and L. Pavlish 1991. The Balof Shelters, New Ireland. In J. Allen and C. Gosden (eds), Report of the Lapita Homeland Project, pp. 46-58. Occasional Papers in Prehistory 20. Department of Prehistory, RSPacS, The Australian National University, Canberra. 
This text is taken from Debating Lapita: Distribution, Chronology, Society and Subsistence, edited by Stuart Bedford and Matthew Spriggs, published 2019 by ANU Press,

The Australian National University, Canberra, Australia.

doi.org/10.22459/TA52.2019.18 